\title{
PEMBELAJARAN DEBAT BAHASA INDONESIA PADA SISWA KELAS X MIPA SMA NEGERI 2 KOTA BENGKULU
}

\author{
'Rini Puspita; ${ }^{2}$ Agus Joko Purwadi; ${ }^{3}$ Rio Kurniawan \\ ${ }^{123}$ Program studi Pendidikan Bahasa Indonesia Fakultas Keguruan dan Ilmu \\ Pendidikan Universitas Bengkulu
}

Abstrak

Korespondensi: rinilizus@gmail.com

Tujuan penelitian ini adalah untuk mendeskripsikan 1) perencanaan pembelajaran debat Bahasa Indonesia pada siswa kelas X MIPA SMA Negeri 2 Kota Bengkulu, dan 2) pelaksanaan pembelajaran debat Bahasa Indonesia pada siswa kelas X MIPA SMA Negeri 2 Kota Bengkulu. Jenis penelitian ini adalah Penelitian Kualitatif yang dilakukan dengan metode deskriptif. Sumber data dalam penelitian ini adalah salah satu guru mata pelajaran Bahasa Indonesia dan siswa kelas X MIPA SMA Negeri 2 Kota Bengkulu. Teknik pengumpulan data dilakukan melalui observasi, wawancara dan dokumentasi. Langkah-langkah analisis data dalam penelitian ini adalah reduksi data, display data/penyajian data, dan verification/penarikan kesimpulan. Hasil penelitian ini menunjukkan bahwa pembelajaran debat bahasa Indonesia pada siswa kelas X MIPA SMA Negeri 2 Kota Bengkulu dilihat dari perencanaan pembelajaran yang dibuat oleh guru sudah melengkapi format komponen-komponen perencanaan pembelajaran, namun pada langkah-langkah pembelajaran guru belum mengarah dan kurang sesuai dengan metode pembelajaran, tujuan pembelajaran dan indikator pencapaian yang tercantum dalam RPP buatan guru. Pencapaian yang telah didapatkan yaitu telah terlaksanakannya pembelajaran dengan langkah pembelajaran yaitu: (1) kegiatan pendahuluan yang mencakup menyiapkan peserta didik secara fisik dan psikis, mengondisikan kelas dengan peserta didik memberi salam pada setiap pertemuan, serta guru memberi penjelasan konsep, tujuan, metode, dan prosedur pembelajaran. (2) kegiatan inti pembelajaran yang mencakup penjelasan materi dengan metode ceramah, pemberian tugas dengan cara bervariasi baik secara individual maupun kelompok. (3) kegiatan penutup yang meliputi refleksi/penarikan kesimpulan dan menutup pembelajaran pada akhir pertemuan. Pada langkah-langkah pembelajaran ada beberapa kegiatan yang tidak berjalan seperti pemberian apersepsi, pemberian motivasi, dan refleksi pada akhir pembelajaran.

Kata Kunci: Pembelajaran, Debat, Perencanaan, Pelaksanaan

\section{Abstract}

The abstract purpose of this study is to describe 1) planning to study Indonesian debate in X MIPA state high school students 2 states of Bengkulu, and 2) implementing the Indonesian language debate course on 2 state high school students. This type of study is qualitative work done with a descriptive method. The source of the data in this study is one of the Indonesian subjects and X MIPA class at the state high school 2 states of bengkulu. Data collection techniques are done 
through observation, interviews and documentation. The data analysis steps in this study are the reduction of data, display of data/presentation of data, and verification/ deduction deduction. This study shows that the Indonesian debate study of X MIPA class at the state high school of Bengkulu is seen from the learning planning made by teachers already complements the format of the components of learning planning, but the teacher's learning measures have not led and are lacking in the learning methods, the purpose of learning and the attainment indicators listed in the teacher's artificial planning and execution of learning. And the achievement it has obtained is that it has accomplished learning with the learning step that is:(1) introductory activities that include preparing physically and psychologically preparing learners, preparing the class with learners greeting each meeting, and teachers explaining the concepts, purposes, methods, and learning procedures. (2) the core learning activity that includes material explanations by the method of the talk, the conferral in a way varies both individually and in groups. (3) the concluding activity includes reflection and closing the study at the end of the meeting. At the steps-learning steps are some activities that do not go such as the granting of conception, the giving of motivation, and the reflection at the end of learning.

Keywords: learning, debate, planning, execution

\section{PENDAHULUAN}

Seiring berjalannya waktu dan zaman semakin berkembang, terjadi perubahan tingkah laku dan perilaku pada manusia dari masa ke masa. Hal ini juga merubah perkembangan sistem pendidikan yang ada di dunia. Pendidikan adalah suatu usaha sadar dan terencana untuk mewujudkan suasana belajar dan proses pembelajaran agar peserta didik aktif mengembangkan potensi dirinya. Perkembangan pendidikan di dunia tidak terlepas dari adanya perkembangan dari revolusi industri yang terjadi pada dunia ini, karena tatanan yang terjadi pada ekonomi akan mempengaruhi tatanan pendidikan di suatu negara. Sekarang ini kita tengah memasuki era globalisasi atau yang dikenal dengan Era Revolusi Industri 4.0, yaitu dimana informasi dan teknologi memengaruhi aktivitas dalam kehidupan sehari-hari termasuk memengaruhi aktivitas di sekolah. Informasi dan pengetahuan dengan mudah menyebar bagi siapa saja yang membutuhkannya.

Fenomena tersebut membuat sistem pendidikan yang ada di dunia mengalami disrupsi yang cukup hebat. Ini disebabkan adanya pergeseran peran guru yang selama ini merupakan satu-satunya sebagai penyedia ilmu pengetahuan sedikit demi sedikit tergeser oleh teknologi canggih sekarang ini seperti internet yang mana semua orang termasuk peserta didik dapat mengakses semua informasi dari internet. Pada masa mendatang, peran guru di dalam kelas akan semakin menantang dalam menyampaikan pembelajaran, oleh karena itu guru sangat membutuhkan kreativitas yang sangat tinggi dalam menyampaikan pembelajaran di kelas.

Menurut Kamus Besar Bahasa Indonesia (KBBI) Pembelajaran merupakan suatu proses, cara, perbuatan untuk menjadikan makhluk hidup untuk belajar. Pembelajaran adalah proses interaksi peserta didik dengan pendidik dan sumber belajar pada suatu lingkungan belajar yang meliputi guru dan peserta didik yang saling bertukar pikiran. Pembelajaran juga merupakan suatu bentuk pendidikan yang memberikan bantuan melalui pendidik agar terjadinya proses pemerolehan ilmu dan pengetahuan, penguasaan kemahiran dan tabiat, serta pembentukan sikap dan kepercayaan pada peserta didik. 
Secara umum Chaer (2003:83) mengartikan pembelajaran sebagai suatu proses pemberian latihan atau pengalaman terhadap seseorang atau sekelompok orang agar terjadi perubahan tingkah laku yang relatif tetap pada orang atau orang-orang itu. Pembelajaran ini dapat dilakukan pada suatu lembaga formal terstruktur maupun pada suatu lembaga secara insidental.

Menurut Undang-undang Sistem Pendidikan Nasional No. 20 Tahun 2003 menyatakan pembelajaran adalah "proses interaksi peserta didik dengan pendidik dan sumber belajar pada suatu lingkungan". Pembelajaran sebagai proses belajar yang dibangun oleh guru untuk mengembangkan kreativitas berpikir yang dapat meningkatkan kemampuan berpikir peserta didik, serta dapat meningkatkan kemampuan mengonstruksi pengetahuan baru sebagai upaya meningkatkan penguasaan yang baik terhadap materi pelajaran. Pembelajaran adalah proses untuk membantu peserta didik agar dapat belajar dengan baik dan bertujuan agar perilaku hasil belajar yang diharapkan terjadi, dimiliki, atau dikuasai oleh peserta didik setelah mengikuti kegiatan pembelajaran tertentu.

Dari uraian di atas, dapat disimpulkan bahwa pembelajaran adalah suatu proses pendidikan yang berisi seperangkat aktivitas yang dilakukan seseorang untuk mengembangkan potensi diri agar dapat dikembangkan secara maksimal dalam mencapai tujuan belajar. Proses pembelajaran mengharuskan pendidik atau guru untuk mengetahui kemampuan yang dimiliki oleh peserta didik meliputi kemampuan dasarnya, motivasinya, latar belakang akademisnya, latar belakang ekonominya, dan lain sebagainya. Pembelajaran bahasa Indonesia pada jenjang pendidikan Sekolah Menengah Atas (SMA) disusun dengan menempatkan bahasa Indonesia sebagai wadah untuk mengembangkan daya tangkap makna, peran, daya tafsir, menilai, dan mengekspresikan diri dengan berbahasa.

SMA Negeri 2 Kota Bengkulu merupakan salah satu lembaga pendidikan jenjang Sekolah Menengah Atas berstatus negeri yang terletak di Jalan Mahoni, Padang Jati, Kecamatan Ratu Samban Kota Bengkulu yang telah menerapkan Kurikulum 2013. Dalam Kurikulum 2013, terdapat beberapa kompetisi keterampilan berbahasa salah satunya adalah keterampilan berbicara yang harus dikuasai peserta didik.

Menurut Sadhonno (2014:53), berbicara merupakan salah satu jenis keterampilan berbahasa ragam lisan yang bersifat produktif. Berbicara secara umum dapat diartikan suatu penyampaian maksud atau bisa berupa gagasan, pikiran, isi hati seseorang kepada orang lain. Sedangkan keterampilan berbicara adalah salah satu keterampilan berbahasa sebagai kemampuan mengucapkan bunyi-bunyi artikulasi atau kata-kata untuk mengekspresikan, menyatakan serta mengungkapkan pendapat atau pikiran dan perasaan kepada seseorang atau kelompok secara lisan, baik secara berhadapan ataupun dengan jarak jauh. Keterampilan berbicara ini sangat erat kaitannya dengan materi yang ada pada Kurikulum 2013 salah satunya adalah materi tentang debat.

Debat adalah suatu kegiatan mengadu argumentasi antara dua pihak atau lebih yang bersifat perorangan ataupun kelompok dengan saling mempertahankan pendapat masing-masing. Menurut Kamus Besar Bahasa Indonesia (KBBI) debat adalah pembahasan atau pertukaran pendapat mengenai suatu hal dengan saling memberi alasan untuk mempertahankan pendapat masing-masing.

Pembelajaran pada Sekolah Menengah Atas, peserta didik dituntut mampu untuk melaksanakan debat bahasa Indonesia baik secara individu maupun secara kelompok. Hal ini tertuang dalam Kurikulum 2013 tepatnya pada KD 3.12: Menghubungkan 
permasalahan/isu, sudut pandang dan argumen beberapa pihak dan simpulan dari debat untuk menemukan esensi dari debat, 4.12: Mengontruksi permasalahan/isu, sudut pandang dan argumen beberapa pihak, dan simpulan dari debat secara ekspresi untuk memperlihatkan esensi dari debat, 3.13: Menganalisis isi debat (permasalahan/isu, sudut pandang dan argumen beberapa pihak, dan simpulan, dan 4.13: Mengembangkan permasalahan/isu dari banyak sekali sudut pandang yang dilengkapi argumen dalam berdebat.

Melalui pembelajaran debat peserta didik dapat mengembangkan keterampilan berbicaranya dan menambah ilmu pengetahuan khususnya dalam pembelajaran debat serta menambah wawasannya. Topik mengenai debat tergolong cukup susah, karena dari hasil wawancara peneliti dengan salah satu guru bahasa Indonesia di SMAN 2 Kota Bengkulu (Bapak Yunial Fahmi, M.Pd.) mengatakan bahwa peserta didik kelas X MIPA masih kurang pemahamannya pada pembelajaran debat disebabkan peserta didik kurang termotivasi untuk giat belajar, kurang fokus dan tidak memperhatikan saat guru sedang menyampaikan materi.

Mengingat pentingnya keterampilan berbicara yang harus dikuasai oleh peserta didik dalam kegiatan pembelajaran, maka tentunya pembinaan terhadap pembelajaran debat harus mendapatkan perhatian yang sungguh-sungguh, baik dari segi peserta didik maupun dari segi guru sebagai tenaga pendidik yang akan membimbing kegiatan belajar. Berdasarkan uraian latar belakang di atas, maka peneliti tertarik untuk melakukan penelitian dengan judul Pembelajaran Debat Bahasa Indonesia pada Siswa Kelas X MIPA SMAN 2 Kota Bengkulu.

\section{METODE}

Penelitian ini menggunakan metode kualitatif yang bersifat deskriptif. Penelitian ini mendeskripsikan perencanaan dan pelaksanaan pembelajaran debat bahasa Indonesia yang dilakukan oleh guru bahasa Indonesia pada siswa kelas X MIPA F dan G SMAN 2 Kota Bengkulu.

Penelitian ini dilakukan di SMAN 2 Kota Bengkulu. Agar penelitian ini sesuai dengan apa yang diharapkan maka peneliti membatasi ruang lingkup penelitian, yaitu hanya dilakukan pada siswa kelas X MIPA F dan G di SMAN 2 Kota Bengkulu. Waktu penelitian Ini berlangsung selama kurang lebih 2 bulan, dari tanggal 16 Maret sampai dengan tanggal 30 April 2020.

Sumber data pada penelitian ini adalah salah satu guru mata pelajaran bahasa Indonesia di SMAN 2 Kota Bengkulu yaitu Bapak Yunial Fahmi, M.Pd. dan siswa kelas X MIPA F dan G SMAN 2 Kota Bengkulu selaku sumber data dalam pembelajaran debat. Data dalam penelitian ini adalah hal yang berkaitan dengan kegiatan pembelajaran debat mulai dari perencanaan pembelajaran, pelaksanaan pembelajaran dan hasil yang diperoleh dari kegiatan pembelajaran yang dilakukan guru bahasa Indonesia dan siswa kelas $\mathrm{X}$ MIPA F dan G SMAN 2 Kota Bengkulu.

Teknik pengumpulan data pada penelitian ini menggunakan teknik observasi, wawancara dan dokumentasi. Dalam penelitian ini instrumen yang digunakan peneliti terdiri atas tiga macam, yakni lembar observasi atau pengamatan, lembar wawancara dan pedoman pencatatan dokumentasi.

Peneliti menggunakan teknik analisis data ada tiga alur yaitu, reduksi data, display data, serta penarikan kesimpulan atau verifikasi. Dalam penelitian ini untuk menguji 
keabsahan data dilakukan dengan triangulasi sumber dengan menggunakan rencana pelaksanaan pembelajaran (RPP) debat dan guru mata pelajaran Bahasa Indonesia. Selain itu, validitas dalam penelitian ini dilakukan oleh dosen pembimbing selama proses bimbingan berlangsung dan diskusi dengan teman sejawat dalam menganalisis Pembelajaran Debat Bahasa Indonesia pada Siswa Kelas X MIPA SMAN 2 Kota Bengkulu..

\section{HASIL DAN PEMBAHASAN}

Hasil

Hasil penelitian ini merupakan data perencanaan pembelajaran debat bahasa Indonesia dan pelaksanaan pembelajaran debat bahasa Indonesia pada siswa kelas X MIPA SMAN 2 Kota Bengkulu.

1. Perencanaan Pembelajaran Debat Bahasa Indonesia pada Siswa Kelas $\mathbf{X}$ MIPA SMA Negeri 2 Kota Bengkulu.

(a) Identitas: dalam RPP yang dibuat informan terdapat bagian status pendidikan SMAN 2 Kota Bengkulu, mata pelajaran Bahasa Indonesia, Kelas X semester genap, materi pokok debat dan jumlah pertemuan 4 kali pertemuan.

(b) Kompetensi inti dan kompetensi dasar: kompetensi inti ada 4 pada kelas $\mathrm{X}$ di Kurikulum 2013 yaitu: (1) menghayati dan mengamalkan ajaran agama yang dianutnya. (2) mengembangkan perilaku (jujur, disiplin, tanggung jawab, peduli, santun, ramah lingkungan, gotong royong, kerja sama, cinta damai responsif dan proaktif) dan menunjukkan sikap sebagai bagian dari solusi atas berbagai permasalahan bangsa dalam menginteraksi secara efektif dengan lingkungan sosial dan alam serta dalam menempatkan diri sebagai cerminan bangsa dalam pergaulan dunia. (3) memahami, menerapkan, menganalisis, dan mengevaluasi pengetahuan faktual, konseptual, prosedural dalam ilmu pengetahuan, teknologi, seni, budaya dan humaniora dengan wawasan kemanusiaan, kebangsaan, kenegaraan, dan peradaban terkait fenomena dan kejadian, serta menerapkan pengetahuan prosedural pada bidang kajian yang spesifik sesuai dengan bakat dan minatnya untuk memecahkan masalah. (4) mencoba, mengolah, dan menyajikan dalam ranah konkret dan ranah abstrak terkait dengan pengembangan dari yang dipelajari disekolah secara mandiri, dan mampu menggunakan metode sesuai kaidah keilmuan. Kompetensi dasar terdapat pada setiap kompetensi mata pelajaran setiap kelas yang diturunkan dari kompetensi inti. Kompetensi dasar terdiri atas kompetensi sikap, pengetahuan, dan keterampilan yang mengacu atau bersumber pada kompetensi inti yang seluruhnya harus dikuasai oleh peserta didik. Kompetensi dasar dapat dikembangkan dengan memperhatikan karakteristik setiap peserta didik.

(c) Indikator pencapaian kompetensi pada RPP informan terdapat bagian-bagian indikator pencapaian: KD 3.12: 1) merumuskan esensi debat, 2) mengidentifikasi unsur-unsur debat, dan 3) merumuskan tata cara debat, KD: 4.12: 1) merumuskan mosi berdasarkan isu atau permasalahan yang sedang berkembang, 2) menganalisis pendapat tim afirmasi, tim oposisi, dan tim netral dalam debat, dan 3) menyimpulkan hasil debat, 3.13: 1) mengembangkan permasalahan/isu dari beberapa sudut pandang yang dilengkapi argumen dalam berdebat, dan 4.13: 
1) menyusun mosi, 2) menyusun pendapat untuk mendukung dan menolak mosi, dan 3) melaksanakan debat sesuai dengan peran yang telah ditetapkan.

(d) Tujuan pembelajaran: $\mathrm{A}=$ peserta didik, $\mathrm{B}=$ dapat menganalisis dan mengembangkan, $\mathrm{C}=$ permasalahan atau isu dari berbagai sudut pandang dan argumen serta mengevaluasi pelaksanaan debat. $\mathrm{A}=$ siswa, $\mathrm{B}=$ dapat mengidentifikasi, $\mathrm{C}=$ isi debat (permasalahan/isu, sudut pandang, argumen beberapa pihak, dan simpulan. $\mathrm{A}=$ siswa, $\mathrm{B}=$ dapat mengidentifikasi, $\mathrm{C}=$ ragam bahasa debat. $\mathrm{A}=$ siswa, $\mathrm{B}=$ dapat menyusun, $\mathrm{C}=$ mosi. $\mathrm{A}=$ siswa, $\mathrm{B}=$ dapat menyusun, $\mathrm{C}=$ pendapat untuk mendukung dan menolak mosi. $\mathrm{A}=$ siswa, $\mathrm{B}=$ dapat melaksanakan, $\mathrm{C}=$ debat, $\mathrm{D}=$ sesuai dengan peran yang telah ditetapkan.

(e) Materi pembelajaran: ciri-ciri debat, unsur-unsur debat, cara mengembangkan argumen dalam debat, macam atau jenis debat, tata cara melakukan debat, mengidentifikasi isi debat (permasalahan/isu, sudut pandang, argumen beberapa pihak, dan simpulan), mengidentifikasi ragam bahasa debat.

(f) Media, alat dan sumber data: Media yang digunakan adalah buku siswa, PowerPoint debat dan video debat. Alat yang digunakan yakni laptop, infokus dan lembar tugas. Sumber belajar yang digunakan oleh guru yakni buku Bahasa Indonesia kelas X, Kementerian dan Kebudayaan Tahun 2014, internet, buku/ sumber lain yang relevan (buku Lomba Debat Bahasa Indonesia), Lembar kerja, contoh esensi dan mosi debat, buku Kementerian Pendidikan dan Kebudayaan 2014 Babasa Indonesia Ekspresi Diri dan Akademik, Jakarta: Kemendikbud. Dan buku Santoso, Ardi. 2004. Menang Dalam Debat. Semarang: Elfhar.

(g) Alokasi waktu: pada KD.3.12 dan KD.4.12 dengan alokasi waktu 4 x 45 menit ( 2 x pertemuan) dan pada KD 3.13 dan KD.4.13 dengan alokasi waktu 4 X 45 menit ( $2 \mathrm{X}$ pertemuan). Jadi jumlah alokasi waktu pada RPP tersebut adalah $8 \mathrm{x}$ 45 menit ( 4 x pertemuan). Namun pada langkah-langkah pembelajaran dalam RPP guru tersebut di KD 3.13 dan 4.13 hanya dilakukan dalam 1 kali pertemuan saja, serta pada saat proses pembelajaran di kelas guru hanya melaksanakan pembelajaran dalam 3 kali pertemuan saja pada materi debat. Sehingga antara alokasi waktu dengan langkah-langkah pembelajaran dan waktu pelaksanaan pembelajaran di kelas tidak sesuai. Informan tidak melakukan alokasi waktu sesuai dengan yang tertera pada RPP dan terkadang waktunya masih kurang sehingga ada beberapa pada saat kegiatan inti dan penutup tidak dilakukan sesuai dengan yang ada pada RPP.

(h) Metode pembelajaran: KD. 3.12 dan 4.12 dengan metode yaitu: metode diskusi, tanya jawab dan praktik, dan pendekatan saintifik pada KD 3.13 dan 4.13 menggunakan metode: PBL (problem Based Learning).

(i) Langkah-langkah pembelajaran: Tahap pendahuluan mencakup: penyiapan peserta didik, menanyakan kehadiran peserta didik, dan pemberian informasi berupa kompetensi, materi, tujuan, manfaat dan langkah pembelajaran yang akan dilaksanakan. Tahap inti mencakup kegiatan yang sesuai dengan pendekatan CLL (communicatif language learning) dan pendekatan saintifik yaitu: mengamati, menanya, mengeksplorasi, mengasosiasi, dan mengomunikasikan. Tahap penutup yang mencakup: menyimpulkan, refleksi, evaluasi, pemberian tugas untuk pertemuan berikutnya. 
(j) Penilaian: penilaian sikap yang terdiri dari perilaku yang diamati, disiplin, jujur, tanggung jawab, dan santun yang penilaian hasilnya dengan menganalisis pendapat Tim Afirmasi, Tim Oposisi, dan Netral dalam debat dan pada saat melakukan praktik debat.

\section{Pelaksanaan Pembelajaran Debat Bahasa Indonesia pada Siswa Kelas $\mathbf{X}$} MIPA SMA Negeri 2 Kota Bengkulu.

(a) Kegiatan Pendahuluan: dari hasil penelitian, pada ketiga pertemuan di kelas X MIPA F dan $G$, sebelum memulai kegiatan inti, guru melakukan kegiatan menyiapkan peserta didik secara fisik dan psikis. Guru juga memberikan penejalasan konsep tujuan, metode, dan prosedur pembelajaran secara umum hampir pada seluruh pertemuan.

(b) Kegiatan inti: pelaksanaan pembelajaran telah terlaksanakan. Guru dalam menyampaikan pembelajaran dengan sangat antusias karena ada beberapa peserta didik yang aktif dalam pembelajaran. Namun masih ada beberapa peserta didik yang masih belum memahami pembelajaran akibat kurang memperhatikan dan kurang fokus saat proses pembelajaran berlangsung. Masih ada peserta didik yang keluar masuk kelas dan ada yang asik mengobrol antar sesama temannya. Hal ini terjadi karena selama mengajar guru tidak memberian motivasi sebelum belajar kepada peserta didik dan hanya membiarkan saja peserta didik yang keluar masuk kelas. Padahal, pemberian motivasi akan sangat berguna agar peserta didik dapat bersikap disiplin. Pada saat pembelajaran berlangsung guru juga tidak mengaitkan materi yang sudah di pelajari pada pertemuan sebelumnya dengan materi yang akan di pelajari. Dalam menyajikan materi guru menggunakan media elektronik seperti proyektor, papan tulis, spidol. Namun metode yang digunakan guru dari hasil pengamatan hanya menggunakan metode ceramah saja, hal ini membuat peserta didik merasa bosan dengan pembelajaran yang bersifat monoton dan satu arah.

Kegiatan penutup: dari hasil pengamatan peneliti di lapangan ditemukan bahwa guru hanya melakukan kegiatan refleksi hanya pada pertemuan pertama di kelas X MIPA F saja. Sedangkan pada pertemuan-pertemuan berikutnya tidak melakukan kegiatan refleksi dikarenakan waktu sudah habis dan mengakhiri pertemuan dengan peserta didik memberi salam kepada guru

\section{Pembahasan}

Berdasarkan analisis data, maka pembelajaran debat bahasa Indonesia pada siswa kelas X MIPA SMA 2 Kota Bengkulu telah terlaksanakan dengan lancar.

\section{Perencanaan Pembelajaran Debat Bahasa Indonesia pada Siswa Kelas $\mathbf{X}$} MIPA SMA Negeri 2 Kota Bengkulu.

Rencana pelaksanaan pembelajaran dijabarkan berdasarkan silabus yang bertujuan untuk mencapai suatu kompetensi dasar. RPP juga membantu guru untuk melaksanakan pembelajaran sesuai dengan yang telah di tetapkan dan guru berkewajiban untuk menyusun RPP secara lengkap dan sistematis. Menurut Kaufman (dalam Harjanto 2010:2), perencanaan adalah suatu proyeksi tentang apa yang diperlukan dalam rangka mencapai tujuan absah dan bernilai. 
Perencanaan pembelajaran Debat Bahasa Indonesia di kelas X MIPA SMA Negeri 2 Kota Bengkulu yang dibuat oleh guru berdasarkan temuan peneliti di lapangan guru telah melengkapi format rencana pelaksanaan pembelajaran (RPP) yang mencakup: 1) identitas Sekolah, 2) identitas mata pelajaran, 3) kelas/semester, 4) materi pokok, 5) alokasi waktu, 6) tujuan pembelajaran, 7) kompetensi dasar dan indikator pencapaian kompetensi, 8) materi pembelajaran, 9) metode pembelajaran, 10) media dan alat pembelajaran, 11) sumber belajar, 12) Langkah-langkah pembelajaran, dan 13) Penilaian. Rusman (2013:119), menyatakan dalam suatu pembelajaran terdapat komponen-komponen dan masing-masing komponen membentuk satu kesatuan yang utuh (integritas).

Pada saat melakukan wawancara kepada informan yaitu Bapak Yumial Fahmi, M.Pd. mengatakan bahwa informan membuat RPP sendiri dan pada proses pembelajaran debat ia sering menggunakan metode ceramah dan saintifik, namun pada RPP yang dibuatnya tercantum sumber belajar yang informan gunakan yakni buku Bahasa Indonesia Ekspresi Diri dan Akademik tahun 2014 dan bukan menggunakan buku yang sesuai dengan Kurikulum 2013. Pada tujuan pembelajaran dalam RPP yang dibuat oleh guru juga kurang terarah dengan indikator pencapaian yang dibuat oleh guru. Pada langkah-langkah dalam RPP yang dibuat oleh guru juga kurang terarah dan tidak sesuai dengan langkah-langkah pembelajaran metode yang tercantum di dalam RPP yakni metode saintifik dan CLL (comunnicative language learning).

2. Perencanaan Pembelajaran Debat Bahasa Indonesia pada Siswa Kelas $\mathbf{X}$ MIPA SMA Negeri 2 Kota Bengkulu.

a. Kegiatan Pendahuluan

Berdasarkan hasil penelitian pada kedua kelas yang masing-masing terdiri atas tiga kali pertemuan, guru memulai pembelajaran berdasarkan komponen-komponen pendahuluan meliputi: menyiapkan peserta didik secara fisik dan psikis, mengondisikan kelas dan penyampaian tujuan pembelajaran. Namun pada kegiatan pendahuluan ini, ada beberapa kegiatan yang belum berjalan seperti pada beberapa pertemuan guru tidak membimbing peserta didik untuk berdo'a sebelum belajar dan guru tidak mengecek kehadiran peserta didik padahal kegiatan ini merupakan kegiatan yang baik untuk dilaksanakan karena kegiatan ini berhubungan dengan penerapan kompetensi spiritual sebagai perwujudan penguatan interaksi vertikal kepada Tuhan Yang Maha Esa.

Pada pertemuan kedua berdasarkan RPP yang dibuat oleh informan dalam kegiatan pendahuluan terdapat kegiatan dimana peserta didik menjawab pertanyaan berkaitan dengan materi pembelajaran pada pertemuan yang lalu. Namun, pada pelaksanaannya guru tidak melaksanakan kegiatan tersebut. Hal ini tak selaras dengan pendapat Daryanto (2014:64) guru membuka kesempatan kepada peserta didik untuk bertanya mengenai apa yang sudah dilihat, dibaca, disimak. Guru seharusnya membimbing peserta didik untuk mengajukan pertanyaan-pertanyaan terkait apa yang dipelajari yang berkenaan dengan fakta, konsep, prosedur atau yang lainnya.

Kemudian pada kegiatan peserta didik menerima informasi kompetensi, materi, tujuan, manfaat, dan langkah pembelajaran yang akan dilaksanakan guru melakukan kegiatan tersebut pada setiap pertemuan dan hanya menjelaskan secara umum saja. Tujuan pembelajaran seharusnya disampaikan dengan jelas dan secara 
berkala agar peserta didik mengetahui tujuan pembelajaran dan dapat memotivasi peserta didik untuk lebih memperhatikan saat belajar. Menurut Uno (2006:7) agar tujuan mudah diketahui, maka tujuan harus dirumuskan secara khusus.

Pada kegiatan pendahuluan ini guru tidak melakukan beberapa kegiatan yang seharusya dilakukan yakni tidak melakukan kegiatan apersepsi atau mengaitkan ilmu pengetahuan atau informasi yang telah di dapatkan pada pertemuan sebelumya dengan ilmu atau informasi yang akan di pelajari. Guru juga kurang memberikan motivasi kepada peserta didik agar blajar lebih giat dan memperhatikan penyampaian materi yang di lakukan oleh guru.

Jadi, kegiatan pendahuluan yang dilaksanakan oleh guru pada pembelajaran debat bahasa Indonesia di kelas X MIPA SMAN 2 Kota Bengkulu berjalan dengan lancar, hanya saja ada beberapa kegiatan yang kurang sesuai dengan langkah pembelajaran yang ada di RPP. Dengan adanya kegiatan pendahuluan, maka pembelajaran akan siap di mulai atau dilaksanakan berdasarkan tahapan Kurikulum 2013 Rusman (2013:11).

b. Kegiatan Inti

Kegiatan inti merupakan kegiatan atau proses pembelajaran yang dilakukan untuk mencapai kompetensi dasar (KD). Kegiatan inti berkaitan dengan penggunaan model pembelajaran, media pembelajaran, sumber belajar dan RPP yang digunakan oleh guru untuk melakukan proses pembelajaran. Dari hasil observasi yang dilakukan oleh peneliti, pada RPP guru di pertemuan pertama dan kedua menggunakan pendekatan CLL (Communicative Language Learning) dengan model pembelajaran yakni Sibtesis pedagogi genre, Saintifik (discovery dan role playing), dan CLIL. Sedangkan pada pertemuan ketiga pada RPP menggunakan pendekatan saintifik dengan model pembelajaran PBL (Problem Based Learning).

Namun pada pelaksanaan pembelajaran debat ini langkah-langkah pada kegiatan inti yang dilakukan oleh guru di pertemuan pertama di kelas X MIPA F guru memulai pembelajaran dengan menyampaikan materi dengan metode ceramah, guru membimbing peserta didik untuk mengamati video debat yang dibagikan di grup WA (whattshap), guru menanyakan tentang pengertian debat dan dilanjutkan dengan guru menyampaikan materi lanjutan. Selanjutnya guru memberikan tugas menganalisis unsur-unsur debat berdasarkan video debat yang telah dibagikan di grup WA tadi dengan berdiskusi dan dilanjutkan dengan peserta didik mempresentasikan hasil kerjanya. Sedangkan pada pertemuan pertama di kelas X MIPA G guru memulai pembelajaran dengan menyampaikan materi dengan media berupa powerpoint dan ditayangkan dengan infokus, guru menanyakan hal berkaitan dengan mosi, selanjutnya guru menyampaikan kembali materi lanjutan, peserta didik mengamati video debat, setelah itu guru memberikan tugas untuk mengidentifikasi unsur-unsur debat berdasarkan video tadi. Selanjutnya peserta didik mempresentasikan hasil kerjanya. Setelah presentasi guru membuat mosi yang akan dibahas pada pertemuan selanjutnya.

Pada petemuan kedua di kelas X MIPA F, guru memulai pembelajaran dengan menyampaiakan materi yang akan dipelajari dengan metode ceramah. Setelah itu guru melakukan kegiatan tindak lanjut dengan memberikan tugas yakni menyusun mosi. Kemudian peserta didik mempresentasikan hasil kerjanya dan peserta didik di bagi ke dalam beberapa kelompok untuk mengerjakan tugas membuat mosi. Sedangkan pada 
pertemuan kedua di kelas X MIPA G guru memulai pembelajaran seperti biasa menyampaikan materi dengan menggunakan metode ceramah, guru membagi peserta didik dalam beberapa kelompok dan memberikan tugas menyusun kalimat atau pendapat berdasarkan mosi yang telah dibuat pada pertemuan sebelumnya. Peserta didik mengumpulkan tugas dan akan ditampilkan pada pertemuan berikutnya.

Pada pertemuan ketiga di kelas X MIPA F guru memulai pembelajaran dengan membimbing peserta didik untuk melakukan praktik debat, debat dimulai dari kelompok kontra dan disanggah dengan kelompok pro. Setelah melakukan kegiatan debat guru dan peserta didik menutup acara debat. Sedangkan pertemuan ketiga di kelas X MIPA G guru memulai pembelajaran dengan menyampaikan bahwa pada hari itu akan melaksanakan praktik debat, namun sebelumnya guru membimbing peserta didik untuk mengatur bangku untuk peserta debat dan membuat aturan debat terlebih dahulu. Lalu peserta didik ditunjuk untuk mewakili kelompok untuk melakukan debat dan pelaksanaan debat pun diakhiri dengan peserta didik dan guru bersama-sama menyimpulkan pendapat-pendapat dari debat yang dilakukan dan menutup acara dengan mengucapkan salam.

Dalam menyampaiakan pembelajaran guru dominan menggunakan metode ceramah sehingga membuat siswa pasif pada saat pembelajaran berlangsung. Dalam pelaksanaan pembelajaran, guru memberikan tugas secara bervariasi kepada peserta didik. selain tugas individu guru juga memberi tugas kelompok untuk dikerjakan bersama-sama. Pemberian tugas yang bervariasi menciptakan suasana belajar yang tidak membosankan. Dalam pembelajaran guru menggunakan media pembelajaran yang bervariatif seperti spidol, papan tulis, laptop, dan infokus. Pada pelaksanaan kegiatan inti pada pertemuan ketiga di kedua kelas guru langsung saja membimbing peserta didik untuk melakukan praktik berdebat tanpa memberikan contoh atau simulasi sebelum melakukan debat, sehingga membuat peserta didik kurang memahami jalannya praktik debat tersebut.

c. Kegiatan Penutup

Pada kegiatan penutup, peserta didik dan guru melakukan tahapan refleksi/menarik kesimpulan/evaluasi atas pembelajaran yang sudah dilakukan pada pembelajaran debat bahasa Indonesia sesuai dengan pernyataan Shoimin (2014:131) langkah guru membantu siswa melakukan refleksi atau evaluasi terhadap penyelidikan mereka dan proses-proses yang mereka gunakan.

Evaluasi dilakukan untuk mengetahui kemampuan peserta didik terhadap suatu materi pembelajaran yang telah diajarkan oleh guru. Pada penilaian kompetensi pengetahuan, guru menggunakan teknik penugasan. Bentuk penugasan yang diberikan guru berbentuk tugas individu dan tugas kelompok. Pada setiap pertemuan pembelajaran debat bahasa Indonesia guru selalu memberikan tugas seperti pada $\mathrm{KD}$ 3.12 dan KD. 4.12 guru mengevaluasi pembelajaran peserta didik dalam merumuskan unsur-unsur debat, merumuskan ciri-ciri debat, merumuskan tata cara debat, menyusun mosi dan menyusun pendapat yang mendukung dan menolak mosi. Sedangkan pada KD 3.13 dan KD. 4.13 guru mengevaluasi pembelajaran peserta didik dengan melihat dari segi kekuatan argumen, kecepatan berpikir, kelancaran berbicara dan kekompakan peserta didik pada saat praktik debat.

Penilaian keterampilan dilakukan oleh guru di akhir pembelajaran. Penilaian keterampilan meliputi tes, penugasan, dan projek. Penilaian keterampilan guru 
memberikan projek untuk meyusun kalimat-kalimat menolak dan mendukung mosi pada debat secara berkelompok dan melakukan praktik debat di depan kelas. Hal ini dilakukan agar peserta didik dapat mengembangkan kreativitasnya dan guru dapat mengetahui kemampuan dan keterampilan peserta didik secara individu maupun kelompok.

\section{PENUTUP}

Berdasarkan hasil analisis hasil penelitian dan pembahasan, bahwa pembelajaran debat bahasa Indonesia pada siswa kelas X MIPA SMA Negeri 2 Kota Bengkulu dapat disimpulkan bahwa:

1. Perencanaan pembelajaran yang dibuat oleh guru sudah melengkapi format komponen-komponen perencanaan pembelajaran, namun pada langkah-langkah pembelajaran guru belum mengarah dan kurang sesuai dengan metode pembelajaran, tujuan pembelajaran dan indikator pencapaian yang tercantum dalam RPP buatan guru.

2. Telah terlaksanakannya pembelajaran dengan langkah pembelajaran yaitu: (1) kegiatan pendahuluan yang mencakup menyiapkan peserta didik secara fisik dan psikis, mengondisikan kelas dengan peserta didik memberi salam pada setiap pertemuan, serta guru memberi penjelasan konsep, tujuan, metode, dan prosedur pembelajaran. (2) kegiatan inti pembelajaran yang mencakup penjelasan materi dengan metode ceramah, pemberian tugas dengan cara bervariasi baik secara individual maupun kelompok. Berdasarkan penelitian, materi yang dijelaskan oleh guru selama proses pembelajaran hanya beberapa yang sesuai dengan $\mathrm{KD}$ dan tujuan pembelajaran pada RPP yaitu ciri-ciri debat, unsur-unsur debat, cara mengembangkan argumen dalam debat, tatacara melakukan debat, mengidentifikasi isi debat (permasalahan/isu, sudut pandang, argumen beberapa pihak, dan simpulan). (3) kegiatan penutup yang meliputi refleksi/penarikan kesimpulan yang dilakukan pada pertemuan pertama di kelas X MIPA F, evaluasi, dan menutup pembelajaran dengan salam yang dilakukan pada akhir pertemuan. Pada langkah-langkah pembelajaran ada beberapa kegiatan yang tidak berjalan seperti pemberian apersepsi, pemberian motivasi, dan refleksi pada akhir pembelajaran. Media yang digunakan oleh informan dalam menyampaikan pembelajaram berupa powerpoint dan video debat. Media tersebut dipilih oleh guru supaya proses pembelajaran tidak membosankan dan peserta didik tidak mudah jenuh dan pembelajaran menjadi menyenangkan. Selain itu, media spidol dan papan tulis digunakan oleh guru agar peserta didik lebih memahami materi yang disampaikan. Metode yang digunakan oleh guru lebih dominan pada metode ceramah. Metode tersebut dipilih dan digunakan dengan menyesuaikan dengan kondisi dan karakter peserta didik.

Berdasarkan kesimpulan di atas, maka beberapa saran yang dapat dipertimbangkan untuk pembelajaran debat bahasa Indonesia yaitu sebagai berikut:

1. Bagi sekolah untuk menyediakan media agar pelaksanaan pembelajaran berjalan dengan baik dan mendapatkan hasil yang maksimal.

2. Bagi guru supaya membimbing pembelajaran sesuai dengan RPP yang telah dibuat dan kreatif, serta lebih banyak menggunakan metode-metode pembelajaran yang bervariasi dalam melakukan. 
Pembelajaran Debat Bahasa Indonesia Pada Siswa Kelas X MIPA SMA Negeri 2 ...

\section{DAFTAR RUJUKAN}

Chaer, A. (2003). Psikolinguistik Kajian Teoritik. Jakarta: PT RINEKA CIPTA.

Daryanto. (2014). Pendekatan Pembelajaran Saintifik. Yogyakarta: Penerbit Gava Media.

Harjanto, (2010). Perencanaan Pembelajaran. Jakarta: Rineka Cipta.Permendiknas. (2003). Peraturan Menteri Pendidikan Nasional No. 20 Tabun 2003 Tentang Sistem Pendidikan Nasional.

Saddhono, K. (2014). Pembelajara Berbahasa Indonesia. Yogyakarta: Graha Ilmu.

Shoimin, Aris. (2014). Model Pembelajaran Inovatif dalam Kurikulum 2013. Yogyakarta: Arruzz Media Rusman. (2013). Belajar dan Pembelajaran Berbasis Komputer. Bandung: Alfabeta.

Uno, Hamzah B. (2006). Perencanaan Pembelajaran. Gorontalo: PT. Bumi Aksara. 